\title{
Perceptions of the family members of children regarding well-child check-ups in the family healthcare strategy
}

\author{
Percepções dos familiares de crianças sobre a consulta \\ de puericultura na estratégia saúde da família \\ Percepciones de los familiares de los niños \\ sobre la consulta de puericultura
}

\author{
Tatiana da Silva Melo Malaquias ${ }^{\mathrm{a}}$ \\ Maria Aparecida Munhoz Gaívab \\ leda Harumi Higarashic
}

\begin{abstract}
A qualitative descriptive study aimed at understanding the perceptions of the family members of children regarding well-child check-ups in the context of attention to child healthcare. Data collection was done using semi-structured interviews of 19 families, in the city of Maringá, in the state of Paraná, Brazil, from December 2012 to February 2013. The data was analyzed using content analysis, a thematic modality, which resulted in the thematic category "Revealing well-child check-ups from the family's point of view" and two secondary categories. The results showed the interviewees' insipient knowledge of well-child check-ups, reflecting the lack of adequate guidance about this type of care. The family members showed a preference for care of children by a pediatrician. Although secondary, the family noted the participation of the nurse in this activity. It is considered extremely important that well-child check-ups are valued by family members in order to promote effective multi-professional participation in this modality of attention.
\end{abstract}

Keywords: Family. Child care. Growth and development. Child health.

\section{RESUMO}

Estudo descritivo qualitativo que objetivou conhecer as percepções dos familiares de crianças sobre a consulta de puericultura no contexto da atenção à saúde infantil. A coleta de dados ocorreu por meio de entrevistas semiestruturadas, na cidade de Maringá, estado do Paraná, Brasil, no período de dezembro de 2012 a fevereiro de 2013, e teve como participantes 19 familiares. Os dados foram analisados pela análise de conteúdo, modalidade temática, da qual emergiu a categoria temática "Desvelando a puericultura sob a ótica dos familiares"e duas subcategorias. Os resultados mostraram um conhecimento incipiente dos entrevistados sobre a consulta de puericultura, refletindo a carência de orientações sobre esse atendimento. Os familiares demonstraram a preferência pelo atendimento da criança pelo médico pediatra. Percebem a participação do enfermeiro nessa atividade, porém de forma secundária. Considera-se imprescindível que a consulta de puericultura seja valorizada pelos familiares, buscando a efetiva participação multiprofissional nessa modalidade de atenção.

Palavras-chave: Família. Cuidado da criança. Crescimento e desenvolvimento. Saúde da criança.

\section{RESUMEN}

Estudio descriptivo cualitativo tuvo como objetivo delinear las percepciones del familiar de los niños sobre la consulta de puericultura en el contexto de atención a la salud del niño. La recolección de datos se realizó a partir de entrevista semiestructurada, en la ciudad de Maringá, estado de Paraná, Brasil, en el período de diciembre de 2012 a febrero de 2013 y tuvo como participantes 19 familiares. Los datos fueron analizados por el análisis de contenido, modalidad temática, en el cual surgió la categoría temática: Desvelando la puericultura en la visión de los familiares y dos categorías secundarias. Los resultados mostraron un conocimiento incipiente de los entrevistados sobre la consulta de puericultura, reflejando la carencia de orientaciones sobre este servicio. Los familiares demostraron la preferencia por la atención del niño por profesional médico pediatra. Notan la participación del enfermero en esta actividad, pero de manera secundaria. Se considera imprescindible que la consulta de puericultura sea valorada por los familiares, de manera a promover la efectiva participación multiprofesional en esta modalidad de atención.

Palabras clave: Familia. Cuidado del niño. Crecimiento y desarrollo. Salud del niño.
D0l: http://dx.doi.org/10.1590/1983-

1447.2015.01.46907

\footnotetext{
Nurse. Masters in Nursing. Professor in the Nursing Department of the Central-Western State University (Universidade Estadual do Centro-Oeste), Guarapuava, Paraná, Brazil.

${ }^{b}$ Nurse. PhD in Nursing. Associate Professor in the Nursing Department at the Federal University of Mato Grosso (Universidade Federal de Mato Grosso), Cuiabá, Mato Grosso, Brazil.

c Nurse. PhD in Education. Associate Professer in the Nursing Department at Maringá State University (Universidade Estadual de Maringá), Maringá, Paraná, Brazil.
} 


\section{口INTRODUCTION}

In the context of basic care, and primarily, that which relates to Family Healthcare Strategy (Estratégia Saúde da Familia - ESF), the care of children is centered on the family, due to the fact that it is made up of a constant element in its life that is developing. Furthermore, the ESF establishes, within the framework of primary health care, that the child/ family should receive care that promotes health and disease prevention, in addition to primary care for any childhood injuries or complications ${ }^{(1)}$.

A well-child visit is an instrument that allows for a child to be followed from shortly after he or she is born until he or she is 10 years old, seeking early guidance from mothers or guardians, allowing for early diagnosis and the prevention of future complications to childhood development ${ }^{(2-3)}$. It is fundamental to encouraging healthy growth and development, so that the child reaches adulthood free of complications that could have been avoided during childhood(4).

A study done in Cuba reports that one of the biggest advances in child healthcare in the $20^{\text {th }}$ century was the reduction of childhood morbidity and mortality, as the result of preventative pediatric care, as the result of wellchild visits ${ }^{(5)}$

Nevertheless, for the well-child visit to be effective, the professional who is responsible for this care, should understand the reality surrounding the life of the child and his or her family, so that he or she can meet the child's real needs ${ }^{(6-7)}$.

The literature also shows that when the professional allows the family to actively participate during the visit and in the decision-making, we see a higher level of satisfaction, better clinical results and better adherence to treatment and guidelines ${ }^{(8)}$.

The family members, especially mothers, should be guided on well-child visits starting with prenatal treatment, establishing a link with the family and beginning preventative guidelines, emphasizing breast feeding and primary care of the newborn. At this time, it is paramount that the mother receives clarifications, not only about the gestational period, but also about the postpartum period and care of the child, facilitating maternal adhesion to wellchild visits $^{(9)}$.

Authors from the Centre for Community Child Health, in Australia, argue that investment in programs and actions that offer support for the families of children, starting with the first years of life, may contribute to early detection of risk factors for the emergence of health problems ${ }^{(10)}$.

The professional experience of the authors of this study have shown that, often times, mothers fail to bring their children for well-child visits, seeking care only when children are sick. Considering that well-child visits are a fundamental activity for the promotion of childhood health, disease prevention and education of the child and the members of his or her family, we asked, in this study, about what understanding the family members of children cared for through the family healthcare strategy have about well-child visits. Thus, the goal of this study was to understand the perceptions of the family members of children about well-child visits in the context of attention to childhood health.

\section{METHOD}

Descriptive research, with a qualitative approach, carried out in the city of Maringá, in the state of Paraná, Brazil, from December 2012 to February 2013, as an integral part of one of the master's dissertation of one of the authors ${ }^{(11)}$. Participants of the study included family members of children enrolled in the Well-child Visit Program (Programa de Puericultura - PP), developed by the Family Healthcare Strategy professionals from one of the city's Integrated Healthcare Centers (Núcleo Integrado de Saúde - NIS). The decision to use this location for the study was made for being the field of practice for Maringá State University's (Universidade Estadual de Maringá) teaching, research and extension programs.

On the NIS family healthcare teams, the physician and nurse are the professionals responsible for the well-child visits, receiving support from nursing assistants/technicians for verification of the anthropometric data. The activities that make up the well-child visits include scheduled care and home visits, which are most often performed by community healthcare agents.

Children from 0 to 10 years old are accompanied by the ESF teams and the parameter for the visits is the timeline established by the Ministry of Health. According to information from the director of the NIS, there is no specific protocol for development of the well-child visits in the city. What does exist is a common protocol for all basic care actions, which is currently being rewritten.

The participants of the study were approached and invited to participate in the research, due to their appearance at the well-child visit during the data collection period. After being duly informed about the goals of the study, their acceptance was recorded in an Informed Consent Form. The criteria for inclusion stated that the participants needed to have a son or daughter/grandson or granddaughter enrolled in the PP and be monitored for at least 6 months. Therefore, 19 families participated 
in the study, with only one family member for each child brought for a visit. The total number of participants was not determined a priori, but to the extent that the goals of the study were reached ${ }^{(12)}$

Data collection was done via interviews, using a semi-structured script, made up of two parts: one centered on the characterization of the study subjects, and the other, pertinent to the approach of the central theme of the study, contained the following guiding question: What is your opinion about well-child visits for the health of your child/grandchild?

The interviews were held at the healthcare facility, in a room reserved for this purpose, and audio recordings were made, in order to allow the interviews to flow better, as well as for reliability of the data collected. To protect the identity of the family members interviewed, they were identified using names of birds, in allusion to the care process implemented, by these beings, of their young.

The data was interpreted using a content analysis technique, in the thematic modality ${ }^{(12)}$. The information was transferred from the audio recorded to the computer and printed to make it easier to read. After various readings of the material, the data that was relevant, and able to meet the goal of the study, was selected. The data was listed according to the most significant units of meaning, contained in the participants' expressions and defined the thematic category of the study: Revealing well-child visits from the family members' point of view, which was broken down into two secondary categories - "The well-child visit and the anthropometry" and "Well-child visits: recognizing interdisciplinary spaces for multidisciplinary action." For discussing the results, we used the literature published about the subject studied as a reference.

During the study, the recommendations in Resolution 196/1996 of the National Board of Health - Ministry of Health, valid at the time the investigation was done, were respected. The project was approved by the Permanent Ethics Committee for Research Involving Human Beings of Maringá State University (Comitê Permanente de Ética em Pesquisas Envolvendo Seres Humanos - COPEP), in accordance with reports 63568/2012 and 147.735/2012.

\section{RESULTS AND DISCUSSION}

\section{Characterization of the participants}

19 family members of the children enrolled in the Wellchild Visit Program participated in the study. Of the participants there were 16 mothers, two grandmothers and one father. The age of the subjects varied from 20 to 24 years old (47.37\%) and 30 and up (36.84\%). With regard to marital status, the highest percentage included people who were married or in stable relationships (73.68\%). As for level of education, 14 had completed high school (73.68\%). With respect to profession, 10 stated that they were housewives (52.63\%).

\section{Revealing well-child visits from the family members' point of view}

The statements made by family members about wellchild visits revealed a lack of knowledge regarding the purpose and importance of these visits in the context of attention to childhood health. The term "well-child visit" was unknown by the majority of the interviewees, as can be seen in the following statements:

Well-child visits... I've heard of it, but I don't know what it is... (Seagull - mother).

I don't know what this name is... well-child visit (Hummingbird-mother).

I think that a well-child visit is the monitoring of the child every month (Harpy Eagle - grandmother).

A study carried out in Sobral, in Ceará(4) verified that the lack of appropriate guidance and communication led mothers to not take their children for well-child visits, considering the care to be "not serious," since the child was not sick. Reiterating this data, research done in São Leopoldo, in Rio Grande do Sul ${ }^{(13)}$ indicated that $66.2 \%$ of the mothers of children that participated in the PP did not bring their children for these visits because they did not consider them to be necessary and $50 \%$ of the children enrolled in the program were not monitored for the first year of life, since the mothers only sought care when the children were sick.

This denotes the need for clarification about the healthcare actions offered to the population attended, in order to allow this population to perceive the benefits that result from participation in the programs directed at promoting health, such as the Well-child Visit Program.

Health education is an essential tool for encouraging childhood health, whether through individual or collective actions, since it allows for the exchange of knowledge among professionals and family members, stimulating significant changes in care given to children ${ }^{(14)}$.

The educational process of the Well-child Visit Program may be developed in both individual visits and group activities, as is done at the Primary Healthcare Centers, in Bar- 
celona, Spain. The work done at these centers, coordinated by nurses, takes place through group dynamics directed at mothers and their children, as well as through the approach to various topics, such as breast feeding, childcare, the maternity process, and others ${ }^{(7)}$. These care scenarios encourage the process of guiding mothers and guardians about childcare, while providing spaces for clarifying doubts and allowing the caregiver to express his or her feelings about the child, strengthening the link between the healthcare service with the user and the family's autonomy for care ${ }^{(15)}$.

\section{Well-child visits and anthropometry}

Although some of the research participants referenced activities related to well-child visits, none of them had a deeper notion about this type of care. The visit was defined based on the description of procedures performed during care of the child at the healthcare facility.

I know that it is to look at size, weight and whether the child is growing according to his or her age, right!? (Heron - mother).

He [the physician] performs an exam, checks reflexes. The girls [nursing assistants], before seeing the doctor, weigh and measure him [the child] and they measure the head. The doctor only performs the exam after (Toucan - mother).

The first step is with the "nurses" [nursing assistants], who weigh and measure him [the child]; and after you go in with the doctor, who asks if everything is ok with the child, if there is something to discuss... (Nightingale - mother).

Research that identified the actions implemented by the nurse during the well-child visit at family healthcare facilities, verified that the most frequent action for evaluating children was anthropometry ${ }^{(15)}$. It is worth emphasizing that, despite techniques such as anthropometric measures being fundamental to accompanying the growth of the child and maintaining his or her health ${ }^{(14)}$, they should not be performed in isolation.

Considering that the ESF has been generating changes in the guidelines of the care practices implemented by the healthcare professionals, childcare implies encouraging reception permeated by attention and affection, attentive listening, dialogue, a connection with the family and accountability for encouraging the community's adhesion to the programs and treatment ${ }^{(16)}$.

We know that well-child visits are one of the primary instruments for promoting the health of children, espe- cially in the most needy communities, contributing to a reduction in childhood morbidity and mortality ${ }^{(5,17)}$. Therefore, the professionals should always be concerned with informing the family members about the actions that will be taken in the PP, as well as the importance of adequately following the calendar of visits for maintaining the health of the child ${ }^{(4,12)}$. Only through this gradual awareness of the population that uses these programs will it be possible to transform the dominant paradigm, characterized by the appreciation of the techniques and medicalization, centering the focus of the attention on integral care of the individual, starting with his or her real health needs.

The healthcare professionals that develop the well-child visit may not lose sight of the importance of educational actions for encouraging childhood health. According to the National Policy for Primary Care ${ }^{(17)}$, the development of health education is part of the work process of the primary care teams, with the purpose of interfering in the health-illness process of the population and expanding social control to protect the quality of life.

Monitoring of the child through primary health care should be done with the participation of the family, considering the socioeconomic and cultural context in which the child is involved. This monitoring should be regular, so that it is possible to detect changes, in a timely manner, thus allowing for the prevention and treatment of health problems as early as possible and in the most effective manner $r^{(10,16)}$.

When considering the family as the subject of their actions, the professionals resort to practices of empowerment, which are at the heart of promoting healthcare, whose principle is to increase the autonomy of individuals and communities ${ }^{(18)}$. The practices of empowerment for promoting childhood health are supported by emancipatory educational activities and interactive dialogues, which include actions for raising awareness, information, consciousness and mobilization for confronting situations, seeking to transform reality ${ }^{(19)}$.

\section{Well-child visit: recognizing interdisciplinary spaces for multidisciplinary action}

A study that discussed the humanization of care for children, from the mothers' point of view, pointed out that one element that generates dissatisfaction amongst the users, in relation to care during the visits, is when the professional neither stimulates, nor encourages the mothers' participation in the care process. This lack of participation creates a gap between mothers/professionals and hinders the development of the subjects' role as someone who is 
also a guardian and an active participant in caring for the health of their children(6).

With regard to the competence for performing the well-child visit, the interviewees pointed to the role of the medical figure, especially the pediatrician.

The visit should be performed by the pediatrician, since he or she is the specialist in the area, right!? (Pigeon - mother).

As far as the visit goes, it should be done by the pediatrician, who is the specialist in the area, since the clinical physician might make a mistake with the prescriptions... (Toucan-mother).

Ah!... it would be best with the pediatrician, since he or she understands children the best (Harpy Eagle - grandmother).

These findings corroborate the conclusions drawn from other studies, such as the research carried out in Rio Grande do Sul ${ }^{(16)}$, which stated that $9 \%$ of mothers that had well-child visits with the nurse, requested that they be referred to the pediatrician, showing that they felt insecure when cared for by other top-level health professionals.

This behavior reflects a narrow understanding of healthcare, still focused on the role of the physician (physician-centered care model). Moreover, this data denotes the lack of knowledge of the user population, with respect to the dynamic of this care process, based on a multidisciplinary approach and the sharing of duties and responsibilities.

The organization of the ESF allows medical hegemony in healthcare to be broken, facilitating the interaction between the professionals and the family, generating a horizontality in the relationship. Specifically with well-child visits, multidisciplinary care may make mothers feel more comfortable to ask questions and clarify doubts and needs they have regarding the care of their child(6).

We emphasize that, in accordance with the recommendations in the Children's Health Manual by the Ministry of Health (2), the well-child visit may be done by either the physician or the nurse. In compliance with this document, in the ESF, care of the children has been done using individualized visits, home visits and through the family's participation in educational groups. Said manual also proposes a minimum calendar for children's health care, establishing seven visits during the first year of life, with a visit within the first 15 days of life, followed by visits at one, two, four, six and nine months and when the child is one year old. During the second year, two visits are recommended, one at eighteen months and the other at 24 months. From the third to sixth year of life, the visits are limited to one a year.

Some of the study's participants perceived the role of the nurse in the well-child visits, although sometimes, as secondary or restricted to the execution of merely technical activities:

The nurse is the one who examines my daughter, she is very attentive (Sparrow - mother).

Here at the Health Clinic he [the child] first sees the nurse, who weighs and measures him, and them sees the family doctor... (Nightingale-mother).

She [the nurse] weights and measures the baby, takes off his/her clothes, listens to the lungs, measures the head and writes it down. If I ask her anything, she responds (Great Kiskadee-mother)

It is necessary to highlight the involvement of the nurse professional in the process of valuation and systemization of the well-child visit, particularly in view of this professional's privileged status in organizing the services, allowing him or her to be constantly in contact with the children and their families.

This closeness encourages a systematized, integral and humanized care, promoting individual and collective changes, strengthening the link and relationship of shared responsibility with the community, so that the population starts to consider the nurse a participant in the treatment, expanding the focus of care ${ }^{(19)}$. The study performed in Barcelona, Spain, showed that the nurses' participation in maternal and child care is valued by the mothers ${ }^{(7)}$.

For their relevance, well-child visits should be performed by professionals committed to child health. The multidisciplinary work process related to the health of the child needs to be a collective project, in which each individual complements each other and has a transformative role, interacting with the community that uses the service, involving it in healthcare ${ }^{(8,20)}$.

In addition to the physician and the nurse, who are responsible for the well-child visits, other professionals that act directly or indirectly in caring for the mother and her child may contribute to promoting the health of the child, such as the community health agents, which are the link between the community and the healthcare team and know the families and their vulnerabilities. Additionally, in the well-visit groups, the mothers may receive nutritional guidelines and guidelines for oral health from nutritionists and dentist; professionals who work in the field of prenatal 
care, labor and delivery care and post partum care, as well as offer significant contributions to establishing the link between the mother and the healthcare facility, guaranteeing greater adhesion to well-child visits ${ }^{(10,15)}$.

\section{GFINAL CONSIDERATIONS}

The statements from the family members about wellchild visits revealed the lack of knowledge about the purpose and importance of said visits, in the context of attention to childhood health.

The well-child visit is an essential tool in the promotion of childhood health. Therefore, the activities related to this care must be understood by the family members in order to prevent irreversible health problems. As these proposals and actions are understood in depth, they become more valued by the population, which therefore reconfigures its conceptions about the health-illness process and envisions a new logic in relation to the healthcare model.

The nurse, for being the foremost professional in the ESF care activities, must take on the responsibility of developing activities that are inherent to the PP, with the support and effective participation of the other health professionals and the community being serviced, expanding his or her actions to beyond the visit, developing educational work that stimulates the conscious adhesion of the families of the children enrolled in the program.

The study has limitations that are intrinsic to the qualitative methodological approach, including the fact that the limited number of subjects does not allow us to make generalizations or inferences about its results and, furthermore, reveals perceptions of only one of the people involved in the well-child visit, the family members.

However, the results found may serve to notify all health professionals that work directly in caring for children, because the statements made by the family members, in addition to expanding comprehension about well-child visits, show the need for more disclosure of this activity in primary care services. The results may also be applied in the teaching of health professionals, especially physicians and nurses, as well as subsidize investments in other research about the topic, taking into account the relevance of this instrument for care of the child by the family and professional practices within the context of primary care.

\section{Q REFERENCES}

1. Pinto JP, Ribeiro CA, Pettengill MM, Balieiro MMFG. Cuidado centrado na família e sua aplicação na enfermagem pediátrica. Rev Bras Enferm. 2010;63(1):132-35.
2. Ministério da Saúde (Brasil). Secretaria de Atenção à Saúde. Departamento de Atenção Básica. Saúde da criança: crescimento e desenvolvimento [Internet]. Brasília; 2012 [cited in 2014 fev 20]. Available in: http://189.28.128.100/dab/ docs/publicacoes/cadernos_ab/caderno_33.pdf

3. Assis LCF,Veríssimo MLÓR. Expectativas e necessidades de acompanhantes de crianças na consulta de saúde. Rev Bras Crescimento Desenvolvimento Hum [Internet]. 2010 [cited 2014 nov 07]; 20(2):317-29. Available in: http://www. revistas.usp.br/jhgd/article/viewFile/19969/22053

4. Neto FRGX, Queiroz CA, Rocha J, Cunha ICKO. Porque eu não levo meu filho para a consulta de puericultura. Rev Soc Bras Enferm. 2010;10(2):51-9.

5. Torre LMP, ÁlvarezMS, LosadaAR, OrtizEC. Calidad de la consulta de puericulturaen escolares. Medisan [Internet].2011 [cited 2014dez12];15(6):7808. Available in: http://bvs.sld.cu/revistas/san/vol_15_6_11/san 08611.pdf

6. Lima KYN, Monteiro Al, Santos ADB, Teixeira GB. Visão de mães sobre a humanização no atendimento da criança na atenção primária à saúde. Cogitare Enferm [Internet]. 2013 [cited 2014 nov 07];18(3):546-51. Available in: http://ojs.c3sl.ufpr.br/ojs/index.php/cogitare/article/view/ 33570/21068

7. Fernández SB, Moreno MFV, Cañaveras RMP. Percepción de la transción a la maternidad: estúdio fenomemológico en la província de Barcelona. Aten Primaria [Internet]. 2013 [cited 2014 dez 12];45(8):409-17. Available in: http://apps.elsevier.es/watermark/ctl_servlet?_f=10\&pident_ articul $0=90247082 \&$ pident_usuario $=0 \& p$ contactid $=\&$ pident_revista $=27 \& \mathrm{t}$ $y=122 \&$ accion $=$ L\&origen $=$ zonadelectura\&web $=z \mid$.elsevier.es\&lan=es\&fiche ro $=27 v 45 n 08$ a90247082pdf001.pdf

8. Maseri AL, Maseri SL, Albarrán JML. ¿Quién acompaña a los pacientes a la consulta pediátrica? el acompañante de los pacientes pediátricos en Atención Primaria. Rev Pediatr Aten Primaria [Internet]. 2012 [cited 2014 nov 07];14:217-24. Available in: http://www.pap.es/files/1116-1518-pdf/ pap_55_04_ive.pdf

9. Ministério da Saúde (BR). Secretaria de Atenção à Saúde. Departamento de Ações Programáticas Estratégicas. Área Técnica de Saúde da Mulher. Pré-natal e puerpério: atenção qualificada e humanizada - manual técnico. Brasília; 2005 [cited 2014 fev 13]. Available in: http://bvsms.saude.gov.br/bvs/publicacoes/ pre-natal_puerperio_atencao_humanizada.pdf

10. Oberklaid F, Baird G, Blair M, Melhuish E, Hall D. Children's health and development: approaches to early identification and intervention. Arch Dis Child [Internet]. 2013 [cited 2014 dez 12];98(12):1008-11. Available in: http://www.ncbi. nlm.nih.gov/pubmed/23968776

11. Malaquias TSM. Percepções da equipe de saúde e dos familiares da criança sobre a consulta de puericultura [dissertação]. Maringá (PR): Programa de Pós-Graduação em Enfermagem, Universidade Estadual de Maringá; 2013.

12. Minayo MCS, organizadora. Pesquisa social: teoria, método e criatividade. 29. ed. Petrópolis, RJ: Vozes; 2010.

13. Vitolo MR, Gama CM, Campagnolo PDB. Frequência de utilização do serviço público de puericultura e fatores associados. J Pediatr. 2010;86(1):80-4.

14. Lima SCD, Jesus ACP, Gubert FA, Araújo TS, Pinheiro PNC, Vieira NFC. Puericultura e 0 cuidado de enfermagem: percepções de enfermeiros da Estratégia Saúde da Família. J Res: Fundam Care On line [Internet] 2013 [cited 2014 mar 3];5(3):194-202. Available in: http://www.seer.unirio.br/index.php/cuidadofundamental/article/view/2163/pdf 836

15. Oliveira FFS, Oliveira ASS, Lima LHO, Marques MB, Felipe GF, Sena IVO. Consulta de puericultura realizada pelo enfermeiro na estratégia saúde da família. Rev Rene. 2013;14(4):694-703. 
16. Gautério DP, Irala DA, Cezar-Vaz MR. Puericultura em enfermagem: perfil e principais problemas encontrados em crianças menores de um ano. Rev Bras Enferm. 2012;65(3):508-13.

17. Ministério da Saúde (BR). Política Nacional de Atenção Básica. Brasilia; 2012 [cited 2013 nov 12]. Available in: http://189.28.128.100/dab/docs/publicacoes/geral/pnab.pdf.

18. Buss PM. Uma introdução ao conceito de promoção da saúde. In: Czeresnia D, Freitas CM, organizadores. Promoção da saúde: conceito, tendência e reflexões. Rio de Janeiro: Fiocruz; 2009. p.15-38.
19. MELO DF, Andrade RD, Silva MAl. Atendimento dos direitos da criança e do adolescente na assistência de enfermagem na atenção primária à saúde. In: Gaíva MAM, Ribeiro CA, Rodrigues EC, organizadoras. Programa de atualização em enfermagem: saúde da criança e do adolescente. Porto Alegre: Artmed; 2013. v.4. p.47-70.

20. Gaíva MAM, Mandu ENT. Promoção da saúde infantil. In: Gaíva MAM, organizadora. Saúde da criança e do adolescente: contribuições para o trabalho de enfermeiros(as). Cuiabá: EdUFMT, 2006. p. 29-41.

\section{Author's address:}

Tatiana da Silva Melo Malaquias

Rua Con. Jesuino Marcondes, 520/34, bl. 09, Santa Cruz 85015-390, Guarapuava, PR

E-mail: tatieangel@yahoo.com.br
Received: 10.05.2014

Approved: 10.02.2015 